\title{
НАПРЯМИ ПІДВИЩЕННЯ КОНКУРЕНТОСПРОМОЖНОСТІ ПОСЛУГ ФАРМАЦЕВТИЧНОГО ПІДПРИЕМСТВА
}

\section{DIRECTIONS OF INCREASING THE COMPETITIVENESS OF PHARMACEUTICAL ENTERPRISE SERVICES}

\author{
Білоус Світлана Петрівна \\ кандидат економічних наук, доцент, \\ Черкаський національний університет імені Богдана Хмельницького \\ ORCID: https://orcid.org/0000-0002-0303-7453 \\ Яковенко Ангеліна Григорівна \\ студентка, \\ Черкаський національний університет імені Богдана Хмельницького \\ ORCID: https://orcid.org/0000-0002-1485-0239 \\ Bilous Svitlana, Yakovenko Anhelina \\ Cherkassy National University named after Bohdan Khmelnytsky
}

\begin{abstract}
3 кожним днем ми можемо спостерігати, як зростає кількість аптечних закладів у кожному місті, а відповідно і в країні в цілому. Поточна економічна ситуація призводить до посилення конкуренції на українському ринку фрармацевтичних послуг і стимулює аптеки України більше уваги приділяти своїй конкурентоспроможності. Це може стосуватися як цінової політики закладу, так і рівня обслуговування у ньому. Найбільш перспективними напрямами підвищення конкурентоспроможності аптечного бізнесу є підвищення рівня сервісу та якості фрармацевтичних послуг. У статті проаналізовано фрармацевтичний ринок нашої країни та розглядаються ключові шляхи підвищення конкурентоспроможності послуг фармацевтичних компаній. Автори розробили низку рекомендацій щодо підвищення рівня конкурентоспроможності аптек. Рекомендації щодо його застосування дають автори.

Ключові слова: конкурентоспроможність, підвищення, фрармацевтичний ринок, аптека, підприємство, послуги.
\end{abstract}

С каждым днем мы можем наблюдать, как растет количество аптечных учреждений в каждом городе, а соответственно и в стране в целом. Текущая экономическая ситуация приводит к усилению конкуренции на украинском рынке фрармацевтических услуг и стимулирует аптеки Украины больше внимания уделять своей конкурентоспособности. Это может касаться как ценовой политики заведения, так и уровня обслуживания в нем. Наиболее перспективными направлениями повышения конкурентоспособности аптечного бизнеса является повышение уровня сервиса и качества фрармацевтических услуг. В статье проанализированы фрармацевтический рынок нашей страны и рассматриваются ключевые пути повышения конкурентоспособности услуг фрармацевтических компаний. Авторы разработали ряд рекомендаций по повышению уровня конкурентоспособности аптек. Рекомендации по его применению дают авторы.

Ключевые слова: конкурентоспособность, повышение, фрармацевтический рынок, аптека, предприятие, услуги.

Competition is something without which no business can exist. Every day we can see how the number of pharmacies is growing in each city, respectively, and in the country as a whole. The current economic situation leads to increased competition in the Ukrainian market of pharmaceutical services and encourages Ukrainian pharmacies to pay more attention to their competitiveness. This may apply to both the pricing policy of the institution and the level of service in it. Despite the fact that there is a large number of pharmacies in Ukraine, there are also such places in the country where there is a shortage of pharmacies. For example, rural areas, where the vast majority live in the elderly, who a priori need medicine. In our opinion, businessmen should think about starting their own business in such areas. The business will be profitable in any case, because the vast majority of them will be monopolists in the market. All people are different and for each there are their own factors, according to which they choose in which pharmacy they buy medicine. However, usually, first of all, buyers pay attention to how quickly you need to buy a drug and where the pharmacy is located. Obviously, they choose the pharmacy that will be closest to the current location of the buyer. Also, people often choose for themselves exactly the pharmacy where the prices are more affordable. However, most of the respondents we interviewed said that the service in the pharmacy, the attitude of the pharmacist, his ability to help, recommend and not impose the product more expensive, but to sell what the buyer asked for is important to them. 
The most promising ways to increase the competitiveness of the pharmacy business are to increase the level of service and quality of pharmaceutical services. The quality of these services, in turn, depends on how well the relationship between management and subordinates of the company, the logistics of goods, the location of the pharmacy and so on. The article analyzes the pharmaceutical market of our country and considers the key ways to increase the competitiveness of pharmaceutical companies. The authors have developed a number of recommendations for increasing the competitiveness of pharmacies. Recommendations for its use are given by the authors.

Keywords: competitiveness, increase, pharmaceutical market, pharmacy, enterprise, services.

Постановка проблеми. Конкурентоспроможність будь-якої компанії, незважаючи на її розмір, залежить від якості її продукції, вдало налагодженої логістики та цін, місцезнаходження, від швидкості обслуговування та надання консультацій, від вміння вирішити будь-яку ситуацію, що склалася під час обслуговування клієнта. Все більшого значення для концепції загального управління якістю, набуває стратегічна спрямованість на споживача. Управління якістю, засноване на сучасних технологіях управління підприємством, а також на контролі якості виробництва та якості роботи як цілого підприємства, так і окремого працівника.

Конкурентоспроможність - це діяльність, спрямована на фрормування серії управлінських рішень, які, відповідно, мають бути спрямовані на протистояння можливим зовнішнім впливам для досягнення лідерства відповідно до стратегічних цілей [1, с. 143]. Для того, щоб мати можливість продовжувати ефективно працювати на ринку та надавати конкурентоспроможні послуги, необхідно стежити за змінами в навколишньому середовищі і мати можливість швидко адаптуватися до них, тобто весь час працювати над удосконаленням програми підвищення конкурентоспроможності підприємства.

Аналіз останніх досліджень і публікацій. Дослідженню проблем розвитку фрармацевтичних підприємств в сучасній науковій спільності присвячено багато наукових праць провідних українських та зарубіжних авторів. Серед них можна виділити праці В.В. Реутова, Н.Г. Вельгоша, Д.Р. Яцкового, О.Б. Янкового, О.О. Гетьмана, Н.В. Карпенка, 3.Н. Мнушко, І.М. Діхтяревої.

Виділення невирішених раніше частин загальної проблеми. Незважаючи на велику кількість наукових праць присвячених вирішенню проблем підвищення конкурентоспроможності послуг підприємств, на нашу думку питання підвищення конкурентоспроможності послуг саме фрармацевтичних підприємств потребує більш глибокого дослідження та аналізу.

Формулювання цілей статті. Метою дослідження $€$ здійснення аналізу робочого процесу фрармацевтичного бізнесу та надання пропозицій, щодо підвищення конкурентоспроможності послуг на фрармацевтичному ринку.

Виклад основного матеріалу. В сучасних умовах господарювання, для підвищення конкурентоспроможності і орінансової стійкості аптек важливого значення набувають нецінові чинники стимулювання споживачів, а якість фрармацевтичного обслуговування. Лікарські засоби приносять користь тільки в умілих руках. Для того, щоб бути конкурентоспроможними, необхідно підвищити якість обслуговування або навіть запропонувати заходи, якими не користуються конкуренти.

Сучасне бізнес-середовище, зокрема український фрармацевтичний ринок, характеризується досить жорсткою конкуренцією, що спонукає операторів шукати нові ефрективні методи підвищення конкурентоспроможності. Слід зазначити, що Україна має один з найвищих показників в Європі, по забезпеченості населення аптеками. В середньому в нашій країні припадає 2 тис. жителів на один аптечний заклад [2, с. 185]. У такому висококонкурентному середовищі інноваційні питання стають актуальними 3 метою підвищення ефрективності бізнесу. Закордонний досвід показує, що однією з необхідних вимог часу $\epsilon$ автоматизація системи обліку аптеки, особливо зважаючи на умови сьогодення.

3 точки зору системи охорони здоров'я аптека - це заклад, що забезпечує населення необхідними лікарськими засобами [3, с. 113]. 3 позиції бізнесу аптека являє собою комерційне підприємство зі складною структурою звітності, необхідністю підтримувати контакти з численними постачальниками, контролювати різні аспекти руху такого специфрічного товару, як лікарські засоби.

Таким чином, аптеки у процесі своєї діяльності регулярно стикаються 3 трудомісткими і затратними по часу бізнес-процесами, а особливо: фрормуванням замовлення, обліком та підготовкою товарів до продажу, моніторингом неякісних лікарських засобів, управлінням запасами, виявленням дефектів, оптимальним переміщенням товарів між аптеками, відпуском препаратів споживачам. Відтак автоматизація цих процесів забезпечує бізнесу 
цілий ряд переваг та змогу бути конкурентоздатними на фрармацевтичному ринку.

Ідея використання автоматизованої системи обліку як невід'ємної складової комплексу заходів по підвищенню ефективності бізнесу була продиктована вимогами часу. Неефективне використання часу на всіх фразах виставлення рахунків для руху товарів, а також у процесі фрормування замовлень та роботи з постачальниками, $є$ однією $з$ ключових передумов автоматизації аптек [4, с. 56].

На початковій стадії необхідно визначитися $з$ постачальником певного виду послуг, за допомогою якого ця ідея може бути реалізована. На основі детального аналізу всіх пропозицій, враховуючи фрункціональність виставлених послуг та економічну доцільність, на нашу думку, в сучасних українських реаліях оптимальним $€$ вибір програмного комплексу «Аптека» яка $є$ системою обліку руху товарів [5, с. 104]. Процес впровадження нової системи обліку займає всього один день.

3 перших же днів використання програмного продукту «Аптека» можна буде відзначити значну економію часу - завдання, на рішення яких раніше йшли години, будуть виконані за декілька хвилин. Програма також приверне увагу своїм простим інтерсейсом і зручним використанням, практично будь-яка операція виконуватиметься натисненням однієї клавіші. Зрозуміло, що цей продукт створений зі знанням специфріки фармацевтичного бізнесу і максимально відповідає потребам фрармацевтів.

Запровадивши дану систему на підприємстві з'явиться можливість не тільки автоматизувати вирішення нагальних завдань, пов'язаних з рухом товарів, але і оптимізувати товарний асортимент. Зазвичай, аптеки працюють 3 декількома постачальниками одночасно, тому вхідний контроль продукції найчастіше пов'язаний 3 рядом труднощів, подолання яких неналежним чином загрожує для аптеки великими неприємностями у відносинах з фріскальними, санітарними та іншими контролюючими службами держави.

Партійний облік дозволяє суворо контролювати залишки товарів, мінімізувати їх пересортування, усувати плутанину цін і серій однакових позицій. Завдяки коду партій можна буде простежити повний шлях конкретної упаковки від постачальника до покупця. Програмний продукт «Аптека» значно спростить перевірку проблемних позицій, забезпечивши можливість своєчасного відстеження строків придатності та реєстрації лікарських засобів, а також серій препаратів, заборонених до реалізації згідно з приписами Державної інспекції з контролю якості лікарських засобів МОЗ України. Таким чином, можна автоматично виключати потрапляння неякісного товару на аптечні полиці [6, с. 56-58].

Як і будь-якій програмі, продукту «Аптека» притаманні не тільки переваги, але й недоліки. Мінусом $€$ те, що ще не всі основні постачальники підключилися до системи електронного документообігу. Тому підприємство буде змушене мінімізувати співпрацю з постачальниками, які не працюють в онлайн-режимі, із-за економічної неефрективності.

Отже, оцінюючи соціальну значимість автоматизації аптеки, можна відзначити підвищення задоволеності клієнтів рівнем і швидкістю обслуговування, можливість впровадження індивідуальних дисконтних програм, що підвищують доступність фрармацевтичної продукції для населення. Природним наслідком при цьому $є$ фрормування стійкої лояльності покупців до даної аптеки і підвищення ефективності бізнесу в цілому. Крім того, співробітники аптеки також відчують позитивний вплив переходу на нову систему обліку, яка поряд зі значною економією часу їм надала велику кількість нових можливостей для якісного виконання роботи.

Для підвищення конкурентоспроможності послуг в аптеках, нами запропоновано наступні пропозиції:

Сервіс. Клієнти завжди цінують сервіс, а він починається 3 фрармацевтичної етики. Кожен відвідувач очікує професійної поради і консультації від фрармацевтичного працівника. Крім цього, важливим $€$ уважне і спокійне відношення провізора до клієнта. Професійна етика фрармацевтичного працівника ґрунтується на принципах просресіоналізму, компетентності, об'єктивності, чесності, незалежності, гуманності, коноріденційності та індивідуальному підході до кожного пацієнта. Також важливим фрактором в підвищенні конкурентоспроможності аптеки $€$ швидкість та якість обслуговування в аптеці. Фармацевтичне обслуговування зводиться до очікування пацієнтів в черзі, пошуку переваг у лікарському забезпеченні порівняно 3 аптеками-конкурентами, опрацювання якісних стандартів обслуговування.

Сервіс 2.0. Сьогодні вже нікого не здивуєш безкоштовною можливістю поміряти тиск в аптеці. Як щодо швидкого тесту на вимірювання рівню цукру в крові? Звісно, що під наглядом фрармацевта. Хвороба цукрового діабету $є$ досить поширеною в наш час, а своєчасне ії виявлення допоможе людям вберегти своє здоров'я і вчасно почати ліку- 
Таблиця 1

Порівняння замовлення в режимі online зі стандартним методом

\begin{tabular}{|c|c|c|}
\hline Найменування процесу & $\begin{array}{c}\text { Замовлення } \\
\text { через електронну пошту } \\
\text { або телефон }\end{array}$ & $\begin{array}{c}\text { Онлайн-замовлення } \\
\text { за допомогою програми } \\
\text { «Аптека» }\end{array}$ \\
\hline Початок робочого дня & $9: 00$ & $9: 00$ \\
\hline Підготовка до роботи & 9:15 & 9:15 \\
\hline $\begin{array}{l}\text { Імпорт прайс-листів } \\
\text { від дистриб'юторів }\end{array}$ & $\begin{array}{c}\text { 9:15-10:00; } \\
\text { залишки станом на } \\
\text { завершення вчорашнього дня }\end{array}$ & $\begin{array}{c}\text { 9:15-9:20; } \\
\text { тільки актуальні залишки на } \\
\text { складі }\end{array}$ \\
\hline $\begin{array}{l}\text { Вибір пропозицій } \\
\text { і відправка замовлення }\end{array}$ & 10:00-12:00 & $9: 20-11: 20$ \\
\hline $\begin{array}{l}\text { Обробка замовлення } \\
\text { постачальником та повернення } \\
\text { дефектури (відмов) }\end{array}$ & $\begin{array}{c}\text { 12:00-15:00; } \\
\text { 13:00-14:00 (обід); } \\
\text { відмови - близько 10\% }\end{array}$ & $\begin{array}{c}\text { 11:20-11:25; } \\
\text { відмови - 0-3\% }\end{array}$ \\
\hline $\begin{array}{l}\text { Повторні замовлення } \\
\text { у інших постачальників }\end{array}$ & 15:00-16:00 & $11: 30-12: 00$ \\
\hline $\begin{array}{l}\text { Доставка товару } \\
\text { по основним замовленням }\end{array}$ & Завтра в першій половині дня & $\begin{array}{c}\text { Сьогодні у другій половині } \\
\text { дня } \\
\end{array}$ \\
\hline $\begin{array}{l}\text { Доставка товару } \\
\text { по повторним замовленням }\end{array}$ & & \\
\hline
\end{tabular}

Джерело: складено автором на основі [6]

вання. Або ж перевірка зору. Якщо раніше на погіршення зору починали скаржитися люди похилого віку, то сьогодні дана проблема $€$ актуальною і серед молоді, гаджети дають про себе знати. Вчасне виявлення проблеми допоможе усунути її з мінімальними ризиками або ж уповільнити процес погіршення зору.

В магазинах/салонах краси на стійці адміністратора чи касі часто пропонують пригоститись цукерками. В аптеці буде доречно пропонувати клієнтам взяти контрацептиви, з метою захисту від хвороб, що передаються статевим шляхом, або ж у період пандемії одноразові маски чи антисептики.

Психологічний вплив. Одним із головних завдань провізора $€$ в першу чергу заспокоїти людину, якщо це необхідно, зміцнити віру пацієнта в його одужання, цілющу силу ліків, фрармацію та медицину в цілому. Для цього працівник окрім профресійних навичок, має володіти і методами психологічного впливу на людей та правильно будувати і регулювати взаємовідносини з відвідувачами.

Виготовлення препаратів. Досить великим попитом користуються препарати, котрі виготовляються провізором під замовлення. Надання такої послуги буде величезним плюсом для аптеки серед конкурентів.

Ланцюг препаратів. Відомий і добре працюючий прийом, який варто запровадити в аптеці: антибіотик + пробіотик, системний препарат + топічний і так далі. Іноді така пропозиція народжується і сама по собі, оскільки часто відвід- увач не знає, розгублений або не може згадати, що йому потрібно (наприклад, купуючи розчин для внутрішньо венного або внутрішньо м'язового введення, він забуває, що потрібен шприц тощо). В першу чергу варто думати про вигоду клієнта, пропонуючи ланцюг препаратів, а також показати, що таким чином ви піклуєтесь про клієнта. Головне не «перегнути палицю» і щоб турбота не перетворилася в нав'язування, цього треба вчитися.

Набори. Різні набори, наприклад, чай + чашка, борошно для випічки + розпушувач тощо, давно стали хітами продажів. Подібний прийом варто взяти на озброєння і аптеці. Набори - перевірена успішна тактика, вони привертають увагу відвідувача, особливо в аптеках з відкритою викладкою. Більш того, в аптечному закладі їх купують охоче, оскільки довіряють якості. Що правда це більше стосується несрармацевтичних товарів. Ідей маса: зубна щітка + паста або нитка (це просто зручно), шампунь + кондиціонер + маска для волосся (може бути і подарунком), сонцезахисний крем + вершки, що закріплюють засмагу і дорожня аптечка (сезонні набори), набори для новонароджених тощо. Вже сорормовані набори більше привертають увагу покупців, адже являються вигіднішою пропозицією, що цінують клієнти.

Цінова політика та дисконтна система. Це визначальний фрактор для людей похилого віку та інших малозабезпечених груп населення. Водночас низькі ціни змушують задуматися про підробку та невиправдану економію на влас- 
ному здоров'ї. Зазвичай покупці шукають не аптеку з низькими цінами, а необхідний препарат, який може коштувати дешевше в дорогій аптеці, ніж у дешевій. Для привернення уваги покупців розробляється система знижок, яка «прив'язує» покупця до певного місця. Це може бути як фріксована знижка, так і накопичувальна. Проте ми радимо постійно вносити корективи в дану систему, або ж чергувати, для стимулювання інтересу споживачів, а також вдосконалюватися та розвиватися у власній справі.

Повнота асортименту. Одним із основних критеріїв вибору аптеки серед споживачів $€$ можливість придбати все необхідне в одному місці. Звісно, що не існує аптек, де можна придбати абсолютно все, але необхідно намагатися максимально до цього наблизитися, мати в асортименті найпопулярніші товари і пропонувати аналоги.

Сезонний асортимент. 3 настанням нової пори року, люди стикаються з сезонними хворобами чи проблемами. Осінь, зима - вірусні респіраторні хвороби, весна - алергії на цвітіння, літо - надокучання комах. Ми радимо аптекам відповідно до сезону мати достатню кількість ліків та навіть у надлишку.

Інтер'єр. Підхід до інтер'єру аптек у відвідувачів різний і всім вгодити важко. Проте опитування показують, що людям хочеться заходити у затишне та добре освітлене приміщення, зі зручним і красиво офрормленим входом, який до всього облаштований пандусом, важливо, щоб були зручно розташовані вітрини, у персоналу був наявний фрірмовий одяг, торговий зал був чистим та просторим. Додатковий імідж аптекам створюють функціональне розміщення меблів, таких як диванчики, крісла, стільці, а для покупців це буде чудовим місцем, де можна відпочити чи дочекатися своєї черги.

Особливості мерчандайзингу. Розумний виклад товарів на вітрині забезпечить вам 50\% продаж щодня. Основним стереотипом поведінки відвідувачів аптеки $€$ те, що вони в першу чергу звертають увагу на товари, що знаходяться на рівні їхніх очей та дивляться завжди з ліва на право. Тож препарати, що розміщені в центральній частині вітрини і розташовані з правої сторони, мають більше шансів бути побаченими і купленими. Для цього вітрини мають бути гарно освітленими та на кожному товарі має бути вказана ціна, яку гарно видно покупцеві.

Режим роботи. Довжина робочого дня фрармацевтичного закладу в першу чергу залежить від його місця розташування. Якщо аптека розташована поблизу житлового комплексу, то ми радимо зробити робочий день не менше як 14 годин. Відкриватися рано і закриватися пізно. Якщо заклад розташований поблизу лікувального закладу - радимо підлаштовуватися під грасрік роботи останнього. Проте найвдалішим та найвигіднішим рішенням, на нашу думку, є цілодобовий грасрік роботи.

Приєднання до сайту Tabletki.ua. Спочатку ресурс був створений для надання необхідної інфрормації про лікарські засоби, або щоб дізнатися інструкцію застосування від виробника. Згодом він став найбільшим порталом, створеним для пошуку та бронювання фармацевтичної продукції в Україні. За допомогою даного сайту люди можуть ознайомитися 3 наявністю лікарських засобів в аптечних закладах на території України (відповідно тих, які приєдналися до системи), проаналізувати ціни та зробити найвигідніше для себе онлайн замовлення, 3 будь-якого міста, яке буде доставлене у найближчу зручну точку видачі. Сайт має зручний інтерфейс, легкий у використанні. Вам необхідно ввести назву товару, який шукаєте, обрати своє місто, проаналізувати запропоновані товари та ціни і замовити. У разі, якщо ви хочете придбати товар прямо в аптеці, то на сайті можна побачити місцезнаходження аптек та графріки їх роботи.

Введення QR кодів.Особливо актуально в період пандемії. 75\% клієнтів даної аптеки мають доступ до інтернету, а значить мають змогу зробити замовлення препаратів та товарів online. Після того, як клієнт сформує своє замовлення на сайті аптеки, він отримає унікальний QR код. Прийшовши в аптеку людина повинна буде відсканувати QR код i матиме змогу швидко забрати вже спаковане своє замовлення. За допомогою такого нововведення ми зможемо скоротити час перебування людей в аптеці, а також знизити ризик інфікування як клієнтів, так і працівників.

Кур'єрська доставка. Замовлення, сформовані на сайті аптеки можуть бути доставлені кур'єром прямо до дверей замовника, за умови, що воно було оплачене онлайн, карткою. Також, для прикладу, за умови, що замовлення перевищуватиме суму 500* грн (“суму встановлює аптека на власний розсуд) - доставка кур'єром буде безкоштовною. Оскільки люди люблять «шару», а таких більше 60\%, навіть якщо їм і не потрібні ліки або товари на таку суму, вони захочуть добрати на суму 500 грн, тільки щоб їм безкоштовно доставили замовлення додому.

Але для того, щоб створити якісне обслуговування в аптеці, необхідно налагоджувати систему і з середини. Пропонуємо менеджерам впроваджувати і такі методи: 
- забезпечити позитивну, сприятливу атмосфреру в колективі;

- створити вимоги до зовнішнього вигляду фрармацевтів: унісорма (зазвичай це медичний халат, шапочка), охайна зачіска (зібране волосся для жінок, стрижка для чоловіків), стриманий макіяж та доглянуті руки - все це викликає довіру у покупців;

- налагоджена система мотивації персоналу забезпечить як персоналу, так і власникам даного бізнесу, плідно працювати заради спільної мети та отримувати кожному свою вигоду;

- необхідно розробити алгоритм спілкування фрармацевта 3 покупцем (загальні фррази вітання, оригінальне прощання), відкритість та щирість провізора у розмові, допоможуть максимально правильно обрати необхідний препарат;

- забезпечити вчасне підвищення кваліфікації своїх співробітників, відвідування ними відповідних тренінгів, курсів, семінарів дозволить якісніше виконувати свою роботу та дізнаватися про щось нове;

- поліпшення умов праці та робочого місця;
- забезпечити вчасну виплату заробітної плати та надання відпустки.

Висновки. В сучасних умовах господарювання просто мати конкурентів на ринку недостатньо, необхідно бути ще й конкурентоспроможним, вміти виділятися серед інших, пропонувати клієнтам щось нове, неординарне, не таке, як у всіх. Задоволення споживача $є$ однією із вирішальних переваг на ринку серед конкурентів. Для налагодження конкурентоздатності фрармацевтичного бізнесу необхідно працювати як на зовнішньому, так і на внутрішньому рівнях.

Перш за все, на внутрішньому рівні, необхідно налагодити систему постачання товарів. Це допоможе фрармацевтам з легкістю користування базою всіх лікарських препаратів і бачити кількість того чи іншого препарату на залишку.

По-друге, підключаються чинники мотивації персоналу, задля плідної праці всього бізнесу і цілі на єдиний високий результат.

По-третє, на зовнішньому рівні, покращується рівень обслуговування клієнтів за допомогу вище наведених пропозицій.

\section{СПИСОК ВИКОРИСТАНИХ ДЖЕРЕЛ:}

1. Реутов В.В., Вельгош Н.Г. Управління конкурентоспроможністю : [монограсрія]. Сімферополь : Таврія, 2018. $200 \mathrm{C}$.

2. Яцковий Д.Р. Сучасні методики оцінки конкурентоспроможності підприємства. Вісник соціально-економічних досліджень. Вип. 4(51). Київ : Веселка, 2016. С. 183-188.

3. Конкурентоспроможність підприємства: оцінка рівня та напрями підвищення : [монограсрія] / за заг. ред. О.Б. Янкового. Одеса : Атлант, 2019. 470 с.

4. Гетьман О.О. Організаційно-економічний механізм підвищення конкуентоспроможності підприємства на засадах маркетингу : монограсрія. Дніпропетровськ : ДДФА, 2020. 208 с.

5. Карпенко Н.В. Маркетингові дослідження : навчально-методичний посібник. Полтава : Місто, 2019. 149 с.

6. Мнушко 3.Н., Діхтярева І.М. Менеджмент і маркетинг в фрармації. Ч. І. Менеджмент у фрармації : Підручник для студентів вузів. Харків : вид-во НФаУ: Золоті сторінки, 2017. 360 с.

\section{REFERENCES:}

1. Reutov V.V., Velhosh N.H. (2018) Upravlinnia konkurentospromozhnistiu: [monohrafiia] [Competitiveness management: [monograph]]. Simferopol: Tavriia.

2. Yatskovyi D.R. (2016) Suchasni metodyky otsinky konkurentospromozhnosti pidpryiemstva [Modern methods of assessing the competitiveness of the enterprise]. Visnyk sotsialno-ekonomichnykh doslidzhen [Bulletin of socio-economic research]. Kyiv: Veselka, pp. 183-188.

3. Yankovy O. B. (ed.) (2019) Konkurentospromozhnist pidpryiemstva: otsinka rivnia ta napriamy pidvyshchennia: [monohrafiia] [Competitiveness of the enterprise: assessment of the level and directions of increase: [monograph]]. Odessa: Pero.

4. Hetman O.O. (2020) Orhanizatsiino-ekonomichnyi mekhanizm pidvyshchennia konkuentospromozhnosti pidpryiemstva na zasadakh marketynhu: monohrafiia [Organizational and economic mechanism of increasing the competitiveness of the enterprise on the basis of marketing: a monograph]. Dnipropetrovsk: DDFA.

5. Karpenko N.V. (2019) Marketynhovi doslidzhennia: navchalno-metodychnyi posibnyk [Marketing research: a textbook]. Poltava: Misto.

6. Mnushko Z.N., Dikhtiareva I.M. (2017) Menedzhment i marketynh v farmatsii. Ch. I. Menedzhment u farmatsii: Pidruchnyk dlia studentiv vuziv Management and marketing in pharmacy. Part I [Management in Pharmacy: A textbook for university students]. Kharkiv: Zoloti storinky. 